\title{
Effect of Biochar, Carpet Waste, FYM and PGPR on Growth and Yield of Rice under Organic Farming System
}

\author{
Ayush Bahuguna, Sachin Sharma*, Janardan Yadav and Neelam Yadav \\ Department of Soil Science and Agricultural Chemistry, Institute of Agricultural Sciences, \\ Banaras Hindu University, Varanasi, 221005, (U.P), India \\ *Corresponding author
}

\section{Ke y w o r d s \\ Biochar, Carpet waste, FYM, PGPR, rice, growth parameters}

\section{Article Info}

Accepted: 12 February 2020 Available Online: 10 March 2020

\section{A B S T R A C T}

Present investigation was aimed for improving growth and yield of crop using waste products of different activities and also useful in ecological stability of soil environment. The experiment was conducted in the organic farming plot of the Institute of Agricultural Sciences, BHU, Varanasi during kharif season of rice crop (Oryza sativa L.) in 2017. The field experiment was laid out in Randomized Block Design with 10 treatments and three replications. It is evident that there is increase in plant height from 79.37 to 99.60 in Control to $\mathrm{T}_{10}$. It was higher in treatment $\mathrm{T}_{10}$ (Biochar + carpet waste + FYM $(2+1+1 \mathrm{t})$ ha $^{-}$

$1+$ PGPR) 99.60cm followed by $\mathrm{T}_{9}\left(\mathrm{BC} 1+\mathrm{CW} 1+\right.$ FYM1 t ha ${ }^{-1}+$ PGPR) 96.53. Significant differences were found between the treatments after application of PGPR in plot. There was a significant increase in the chlorophyll content of the rice crop. The maximum chlorophyll content in rice leaf was found in $\mathrm{T}_{10}$ (Biochar + carpet waste + FYM $(2+1+1 \mathrm{t}) \mathrm{ha}^{-1}+$ PGPR $)$ i.e. 45.93 followed by $\mathrm{T}_{7}\left(\mathrm{BC} 1+\mathrm{CW} 1+\mathrm{FYM} 1 \mathrm{t} \mathrm{ha}{ }^{-1}+\right.$ PGPR).In treatment $\mathrm{T} 2\left(\mathrm{BC} 1+\mathrm{CW} 1 \mathrm{t} \mathrm{ha}^{-1}\right)$ increase in chlorophyll over control was $2.20 \%$, while $\mathrm{T}_{6}$ (PGPR) increased $12.77 \%$ and in $\mathrm{T}_{10}$ (Biochar + carpet waste + FYM $(2+1+1 \mathrm{t}) \mathrm{ha}^{-1}+$ PGPR) increased $23.76 \%$. Application of graded level of biochar, carpet waste FYM and PGPR was found to significantly enhance the straw and grain yield of rice. Application of $\mathrm{BC} 2$, CW1 FYM1 and PGPR was found $60.17 \%$ higher over the treatment $\mathrm{T} 1$ (control). Grain and straw yield of rice significantly increased with the application of graded level BC, CW, FYM and PGPR the increase was found $92.8 \%$ higher over control $\mathrm{T}_{1}$.It can be concluded that using of these organic sources has good impact on the soil health under long term.

\section{Introduction}

Rice (Oryza sativa L.) is one of the most important cereal crops belonging to the Poaceae family Oryza genus, ranked first among the three major cereals followed by wheat and maize. It provides more than 50 percent caloric intake for one out of three people on earth, shaping the lives of millions of people. Rice provides $21 \%$ of global human energy per capita and $15 \%$ of protein per capita (FAO, 2011). Among the rice developing nations on the planet, India has the largest rice trim zone (around 45 million ha) and second-place positions alongside China (IRRI 2016, Standard Rice Assessment 
Framework). Essentially, the Indian rice generation is expected to be around 109 meters in 2016-17, which is the most amazing ever rice creation to date (AICRIP annual gathering 2017).

Biochar is charcoal used as soil modification Biochar is a stable solid, rich in carbon that can last in soil for thousands of years. Like most charcoal, biochar is made from biomass via pyrolysis Biochar is being investigated as a carbon sequestration approach. Therefore, Biochar has the potential to help mitigate climate change through carbon sequestration Independently, biochar can increase soil fertility of acidic soil (low $\mathrm{pH}$ soil), raise agricultural productivity, and provide protection against certain foliar and soil-borne diseases. Most of the experiments were conducted in low fertility soils, including tropical soils, and in general, major yield improvements were achieved when biochar was applied to such soils, up to $300 \%$ above adequate, unamended control (reviewed by Van Zwieten et al., 2010).

The PGPR refers to the rhizobacteria that exert the beneficial effect on plant growth. PGPR inoculants promote plant growth through at least one mechanism; improved nutrient acquisition by atmospheric nitrogen fixation and nutrients solubilization, suppression of plant disease and or phytohormone production. PGPR stimulate plant growth directly either by synthesizing hormones, by phosphate solubilization or generally by accelerating mineralization process. They can also stimulate growth indirectly by acting as biocontrol agent by protecting the plant against soil born fungal pathogens or deleterious bacteria. Some PGPR suppress pathogen by synthesizing metabolites (Vassilev et al., 2006).Positive interaction between biochar and PGPR resulted in improved growth attributes and biomass yield in switch grass (Shanta, 2012).
Degradation of organic matter in soil is mainly biochemical in nature involving hydrolysis and oxidation brought about by various hydrolytic enzymes liberated by microorganisms. The actinomycetes participated mostly in decomposition of resistant component of plant residue and formation of humus. Farmyard manure is easily available, cheap, proven source of nutrition and has been traditionally used by farmers (Nanda et al., 2016).Application of FYM along with PGPR improved organic carbon, available $\mathrm{N}, \mathrm{P}$ and $\mathrm{K}$ content in soil when applied in mung bean (Das and Singh, 2014). Organic waste materials are available in huge amounts in the form of farm and industrial wastes i.e. carpet wastes generated in huge amount from carpet industry. Organic carbon pools in Indian soils is declining due to heavy and imbalanced incorporation of chemical fertilizers and ignorance or unavailability or inaccessibility of the organic matter. Considering all these facts in Indian context there is a need to study the combined effect of Biochar, FYM, Carpet waste and PGPR as a source of organic material to soil.

\section{Materials and Methods}

The experiment was conducted at the Research Farm, Institute of Agricultural Sciences, Banaras Hindu University and Varanasi. In the experiment, three replications of each treatment were maintained. There were 30 experimental plots along with three control plots (without any treatment). The experiment was laid out in Randomized Block Design. To determine the preliminary physicochemical properties Representative soil samples were collected from five different locations before the $0-20 \mathrm{~cm}$ depth experiment was conducted. The soil belongs to the class of sandy clay loam texture. The soil had a pH of 7.82 (Sparks 1996), EC 0.18 $\mathrm{dSm}^{-1}$ (Sparks 1996) and Organic carbon of $0.49 \%$ (Walkley and Black, 1934). The initial 
soil was low in available $\mathrm{N} 218.02 \mathrm{~kg} \mathrm{ha}^{-1}$ (Subbiah and Asija, 1956), medium unavailable $\mathrm{P}_{2} \mathrm{O}_{5} 12.80 \mathrm{~kg}^{-1}$ (Olsen, 1954) and medium in available $\mathrm{K}_{2} \mathrm{O} 216.70 \mathrm{~kg} \mathrm{ha}^{-1}$ (Hanway and Heidal, 1952).

\section{Results and Discussion}

\section{Effect on plant height of rice}

The data pertaining to effect of biochar, Carpet waste, FYM and PGPR on height of plant are shown in Fig 1. It is clear that in Control $\left(\mathrm{T}_{1}\right)$ to $\mathrm{T}_{10}$ there is an increase in plant height from 79.37 to 99.60 . It was higher in $\mathrm{T}_{10}$ treatment (Biochar + carpet waste + FYM $(2+1+1 \mathrm{t}) \mathrm{ha}^{-1}+$ PGPR $) 99.60$ $\mathrm{cm}$ followed by $\mathrm{T}_{9}(\mathrm{BC} 1+\mathrm{CW} 1+\mathrm{FYM} 1 \mathrm{t}$ ha ${ }^{1}+$ PGPR) 96.53. Significant differences were found between treatments after plot application of PGPR. Treatment $\mathrm{T} 7(\mathrm{BC} 1+$ CW1 t ha ${ }^{-1}+$ PGPR) was found at a plant of $95.53 \mathrm{~cm}$ plant height followed by $\mathrm{T} 2$ (BC1 + CW1 t ha) $\quad 93.45 \mathrm{~cm}$ and treatment T6 (PGPR) $80.39 \mathrm{~cm}$ followed by $\mathrm{T} 1$ (control) $79.37 \mathrm{~cm}$ and are statically equal to each other. Mathivanan et al., (2005) reported that application of PGPR significantly increased the plant height over control. The increase in plant height may be attributed due to adequate supply of nutrients by the PGPR.

\section{Effect on Chlorophyll content}

Data on the chlorophyll content of the leaf as influenced by the application of biochar, carpet waste, FYM and PGPR are shown in Fig 1. There was a significant increase in the rice crop's chlorophyll content. The maximum chlorophyll content in rice leaf was found in T10 (Biochar + carpet waste+ FYM $(2+1+1$ t) ha-1+ PGPR) i.e. 45.93 followed by $\mathrm{T} 7$ $\left(\mathrm{BC} 1+\mathrm{CW} 1+\mathrm{FYM} 1 \mathrm{t} \mathrm{ha}^{-1}\right)$. In T2 treatment
$(\mathrm{BC} 1+\mathrm{CW} 1 \mathrm{t}$ ha-1), the increase in chlorophyll over control was $2.20 \%$, while T6 (PGPR) increased $12.77 \%$ and T10 (Biochar + carpet waste + FYM $(2+1+1$ t) ha-1 + PGPR) increased $23.76 \%$.

\section{Effect on no of tillers per hill}

A critical analysis of the data shown in Figure 1 revealed that there was a significant increase in the number of tillers between treatments. The maximum number of tillers was noted in T10 (Biochar + carpet waste+ FYM $\left(2+1+1\right.$ tha $^{-1}+$ PGPR $)$ and the minimum number of tillers (10.00) in $\mathrm{T} 1$ (Control). The T2 (BC1 + CW1 t ha $\left.{ }^{-1}\right)$, T9 (BC1+ CW1+ FYM1 t ha-1+ PGPR) and T10 (Biochar + carpet waste+ FYM $(2+1+1$ t) $\mathrm{ha}^{-1}+$ PGPR) were therefore statically matched.

\section{Effect on panicle length}

The data depicted in Figure1 revealed that there is increase in the panicle length was found. The maximum no of panicles $(27 \mathrm{~cm})$ found in T10 (Biochar + carpet waste + FYM $(2+1+1 \mathrm{t})$ ha-1 + PGPR) and minimum no of panicle $(16 \mathrm{~cm})$ in $\mathrm{T} 1$ (Control). The application of biochar and carpet waste in treatment $\mathrm{T} 2$ ( BC1 + CW1 tha-1) increases number of panicles $12.5 \%$ over the control, while in T6 alone (PGPR) increase the panicle length by $37.5 \%$ and T10 (Biochar + carpet waste + FYM $(2+1+1$ t $)$ ha- $1+$ PGPR $)$ increased $68.75 \%$ over control . Therefore, the T2 (BC1 + CW1 t ha-1), T9 (BC1 + CW1 + FYM1 t ha-1 + PGPR) and T10 (Biochar + carpet waste + FYM $(2+1+1$ t) ha-1 + PGPR) were found statically at par with each other.

Effect of biochar, carpet waste, FYM and PGPR on grain and straw yield of rice at harvest 
Table.1 Details of treatments followed in the field experiment

\begin{tabular}{|c|c|}
\hline Treatments & Details of Treatment \\
\hline \multicolumn{2}{|l|}{$\mathrm{T}_{1}$ Control } \\
\hline $\mathrm{T} 2$ & Biochar + carpet waste $(1+1 \mathrm{t}) \mathrm{ha}^{-1}$ \\
\hline $\mathrm{T} 3$ & Biochar + carpet waste $(2+1 \mathrm{t}) \mathrm{ha}^{-1}$ \\
\hline $\mathrm{T} 4$ & Biochar + carpet waste + FYM $(1+1+1 \mathrm{t}) \mathrm{ha}^{-1}$ \\
\hline T5 & Biochar + carpet waste + FYM $(2+1+1 \mathrm{t}) \mathrm{ha}^{-1}$ \\
\hline T6 & PGPRconsortium \\
\hline $\mathrm{T} 7$ & Biochar + carpet waste $(1+1 \mathrm{t}) \mathrm{ha}^{-1}+\mathrm{PGPR}$ \\
\hline T8 & Biochar + carpet waste $(2+1 \mathrm{t}) \mathrm{ha}^{-1}+\mathrm{PGPR}$ \\
\hline T9 & Biochar + carpet waste + FYM $(1+1+1 \mathrm{t}) \mathrm{ha}^{-1}+\mathrm{PGPR}$ \\
\hline $\mathrm{T}_{10}$ & Biochar + carpet waste + FYM $(2+1+1 \mathrm{t}) \mathrm{ha}^{-1}+$ PGPR \\
\hline
\end{tabular}

Table.2 Effect of Biochar, Carpet waste, FYM and PGPR on yield of rice

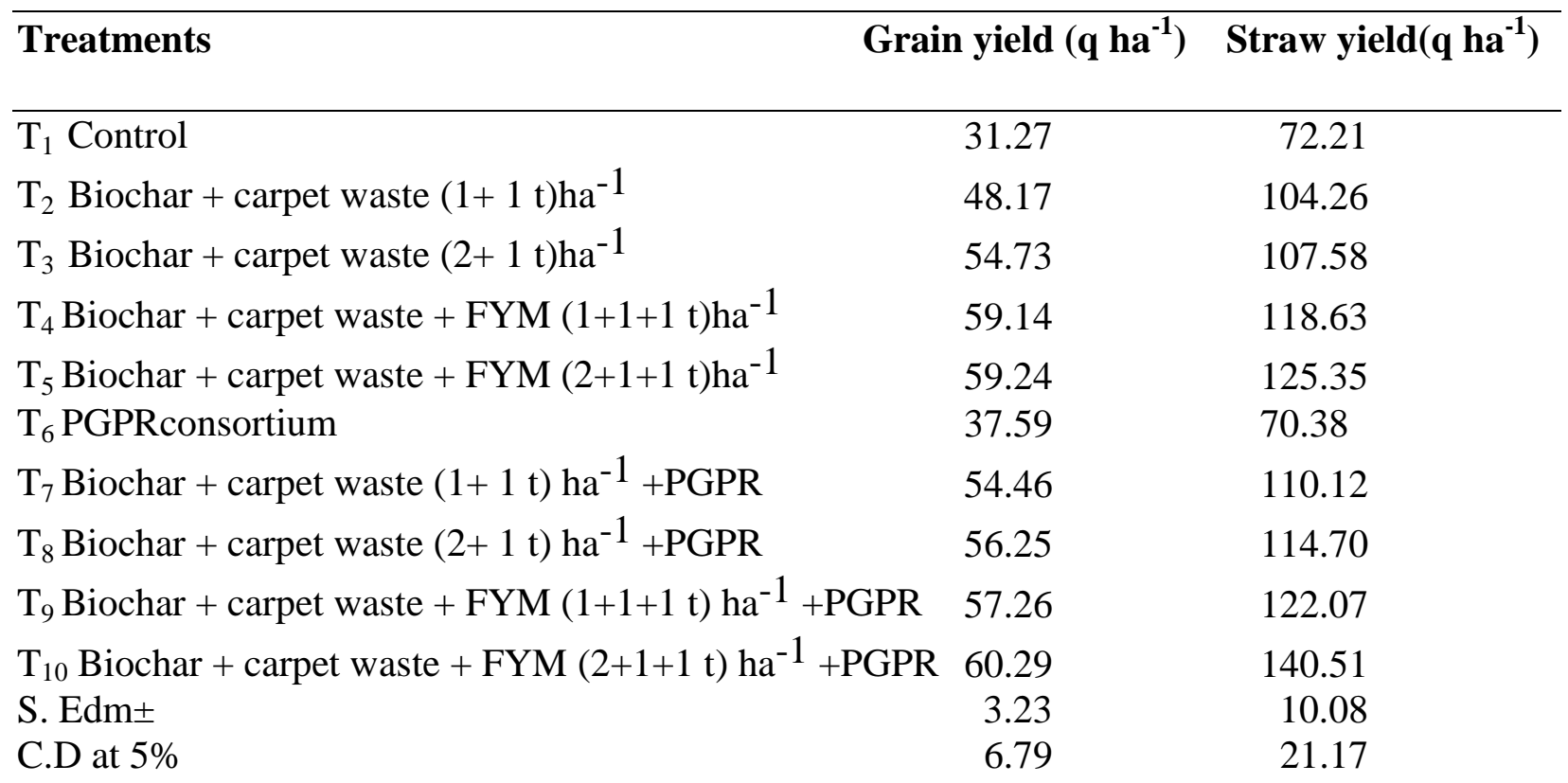


Table.3 Effect of biochar, carpet waste, FYM and PGPR on chlorophyll in leaves, no of tillers and yield attributes of rice

\begin{tabular}{|c|c|c|c|c|c|}
\hline \multicolumn{2}{|c|}{ Treatments } & \multirow{2}{*}{$\begin{array}{c}\text { Plant ht. (cm) } \\
79.37\end{array}$} & \multirow{2}{*}{$\begin{array}{c}\text { Chlorophyll }(\mu \mathrm{g} \mathrm{ml})^{-} \\
\text {1) } 60 \text { DAS } \\
37.11\end{array}$} & \multirow{2}{*}{$\begin{array}{c}\begin{array}{c}\text { No. of } \\
\text { tillershill }^{-1}\end{array} \\
10.00\end{array}$} & \multirow{2}{*}{$\begin{array}{l}\begin{array}{c}\text { Panicle } \\
\text { length } \\
(\mathrm{cm})\end{array} \\
16.00\end{array}$} \\
\hline $\mathbf{T}_{\mathbf{1}}$ & Control & & & & \\
\hline $\mathbf{T}_{\mathbf{2}}$ & Biochar + carpet waste $(1+1 \mathrm{t}) \mathrm{ha}^{-1}$ & 93.45 & 37.93 & 12.80 & 18.00 \\
\hline $\mathbf{T}_{\mathbf{3}}$ & Biochar + carpet waste $(2+1 \mathrm{t}) \mathrm{ha}^{-1}$ & 91.33 & 33.93 & 13.08 & $\mathbf{1 7 . 0 0}$ \\
\hline $\mathbf{T}_{4}$ & $\begin{array}{l}\text { Biochar + carpet waste + FYM }(1+1+1 \mathrm{t}) \\
\mathrm{ha}^{-1}\end{array}$ & 90.28 & 35.06 & 13.77 & 18.26 \\
\hline $\mathbf{T}_{\mathbf{5}}$ & $\begin{array}{l}\text { Biochar + carpet waste + FYM }(2+1+1 \mathrm{t}) \\
\text { ha }^{-1}\end{array}$ & 92.41 & 41.42 & 14.43 & 18.80 \\
\hline $\mathbf{T}_{6}$ & PGPR consortium & 80.39 & 41.85 & 14.43 & 21.00 \\
\hline $\mathbf{T}_{7}$ & $\begin{array}{l}\text { Biochar + carpet waste }(1+1 \mathrm{t}) \mathrm{ha}^{-1}+ \\
\text { PGPR }\end{array}$ & 95.53 & 43.35 & 15.53 & 22.26 \\
\hline $\mathbf{T}_{\mathbf{8}}$ & $\begin{array}{l}\text { Biochar }+ \text { carpet waste }(2+1 \mathrm{t}) \mathrm{ha}^{-1}+ \\
\text { PGPR }\end{array}$ & 92.07 & 41.82 & 14.40 & 23.00 \\
\hline $\mathbf{T}_{\mathbf{9}}$ & $\begin{array}{l}\text { Biochar + carpet waste + FYM }(1+1+1 \mathrm{t}) \\
\mathrm{ha}^{-1} \\
+ \text { PGPR }\end{array}$ & 96.53 & 38.86 & 16.97 & 25.33 \\
\hline $\begin{array}{l}\text { T1 } \\
\mathbf{0}\end{array}$ & $\begin{array}{l}\text { Biochar + carpet waste }+ \text { FYM }(2+1+1 \mathrm{t}) \\
\text { ha }^{-1} \\
+ \text { PGPR }\end{array}$ & 99.60 & 45.93 & 19.47 & 27.00 \\
\hline & $\underset{\mathbf{m} \pm}{\mathbf{S . E d}}$ & 0.18 & 4.07 & 0.37 & 1.17 \\
\hline & C.D at $5 \%$ & 0.39 & 8.54 & 0.78 & 2.47 \\
\hline
\end{tabular}




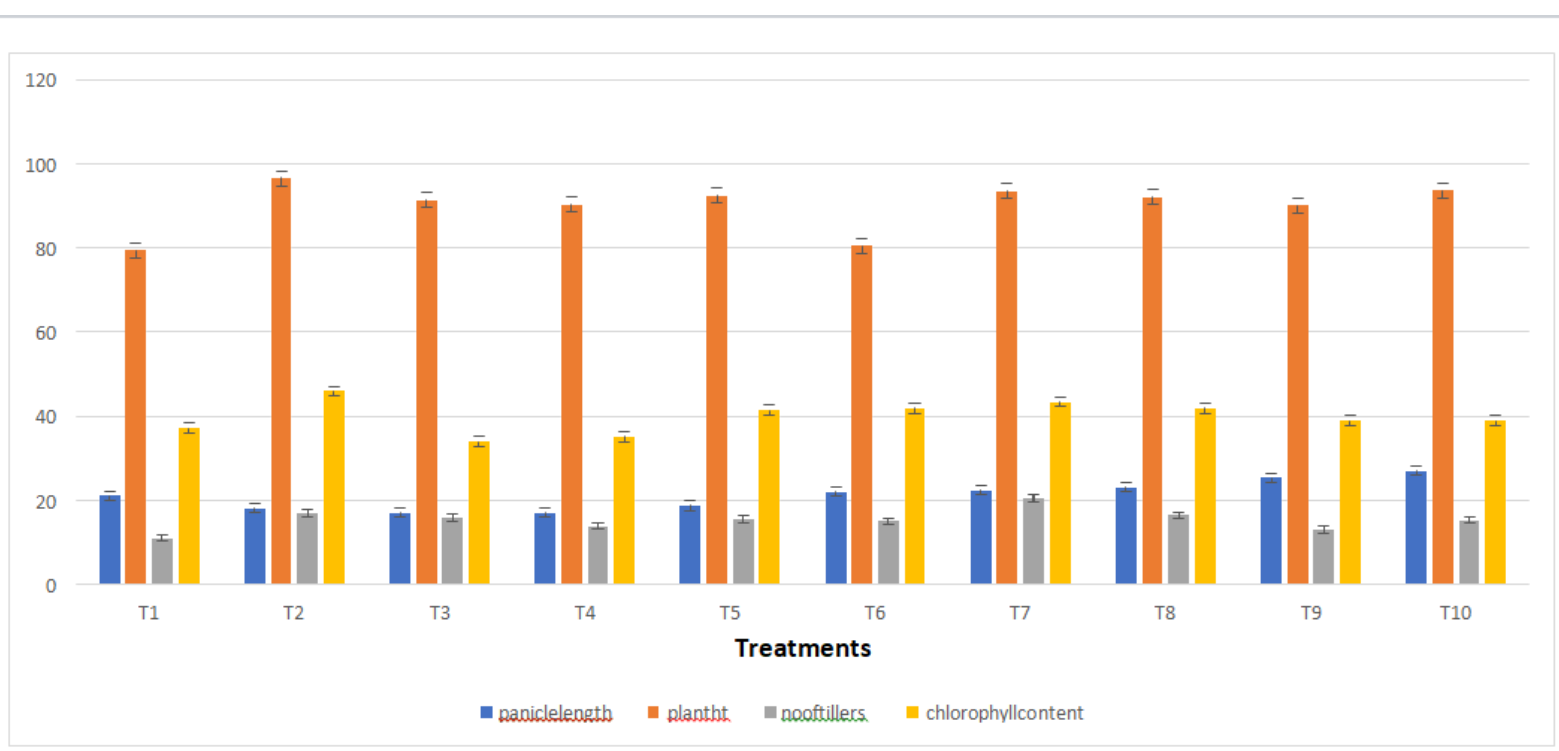

Fig.1 Effect of biochar, carpet waste, FYM and PGPR on chlorophyll in leaves, no of tillers and yield attributes of rice

\section{Effect on grain yield}

A critical perusal of the data presented in Table 3 revealed that the grain yield of rice was ranging from 31.27 to $60.29 \mathrm{qha}^{-1}$. The maximum grain yield $\left(60.29 \mathrm{qha}^{-1}\right)$ was recorded in the T10 (Biochar + carpet waste + FYM $\left(2+1+1 \mathrm{t} \mathrm{ha}^{-1}+\right.$ PGPR $)$ which was $1.77 \%$ higher than treatment T5 (59.24) (BC2 $\left.+\mathrm{CW} 1+\mathrm{FYM} 1 \mathrm{t} \mathrm{ha}{ }^{-1}\right)$. The treatment T10 (Biochar + carpet waste + FYM $\left(2+1+1 \mathrm{t} \mathrm{ha}^{-1}\right.$ + PGPR) was found $92.8 \%$ higher over the treatment $\mathrm{T} 1$ (Control). The treatment $\mathrm{T} 7$ (BC1 + CW1 t ha ${ }^{-1}$ PGPR) gave $54.46 \mathrm{qha}^{-}$ ${ }^{1}$ grain yield which was $13.0 \%$ higher over T2 $\left(\mathrm{BC} 1+\mathrm{CW} 1 \mathrm{t} \mathrm{ha}^{-1}\right)$.

Treatment T6 (PGPR) gave 20.21\% higher grain yield over the T1 (Control). But, the treatment $\mathrm{T} 2\left(\mathrm{BC} 1+\mathrm{CW} 1 \mathrm{t} \mathrm{ha}^{-1}\right), \mathrm{T} 3(\mathrm{BC} 2+$ CW1 t ha $\left.{ }^{-1}\right)$, T9 $\left(\right.$ BC1 + CW1 + FYM1 tha ${ }^{-1}+$ PGPR) and T10 (Biochar + carpet waste + FYM $\left(2+1+1 \mathrm{t} \mathrm{ha}{ }^{-1}+\right.$ PGPR $)$ were found statically at par to each other. Rodon et al., (2007) reported that the bean yield increased by $46 \%$ and biomass production by $39 \%$ over the control at application of $60 \mathrm{~g}$ biochar per $\mathrm{kg}$ soil.

\section{Effect on straw yield}

A critical perusal of the data presented in Table 2.revealed that the maximum straw yield (140.51 $\left.\mathrm{qha}^{-1}\right)$ yield was recordedin treatment T10 (Biochar + carpet waste + FYM $\left(2+1+1 \mathrm{t} \mathrm{ha}^{-1}+\right.$ PGPR $)$ which was 94.58 $\%$ increased over control T1and 12\% increased over treatment $\mathrm{T} 5(\mathrm{BC} 2+\mathrm{CW} 1+$ FYM1 $\left.\mathrm{t} \mathrm{ha}^{-1}\right)$. The straw yield in treatment $\mathrm{T} 7$ (Biochar + carpet waste $(1+1 \mathrm{t}) \mathrm{ha}^{-1}+$ PGPR) was found (110.12 qha-1) which was 5.62\% higher over the T2 ( $\mathrm{BC} 1+\mathrm{CW} 1 \mathrm{t}$ ha-1) .Treatment T6 (PGPR) gave 3.00\% higher over T1 (Control). Significant increase in straw yield was might be due to the availability of all essential elements to the rice crop in sufficient amount by the FYM, carpet waste and PGPR application.

\section{References}

Das, I. and Singh, A. P. (2014). Effect of PGPR and organic manures on soil properties of organically cultivated mungbean. The Bioscan9, 27-29.

Hanway, J. J., and Heidel, H. (1952) Soil analysis methods as used in Iowa state 
college soil testing laboratory. Iowa agriculture 57.

Mathivanan, N., Prabavathy, V. R., \& Vijayanandraj, V. R. (2005). Application of talc formulations of Pseudomonas fluorescens Migula and Trichoderma viride Pers. ex SF Gray decrease the sheath blight disease and enhance the plant growth and yield in rice. Journal of Phytopathology, 153(11-12), 697701.

Nanda, G., Meena, R. K., Sravan, U. S. and Singh, S. P. (2016). Effect of NPK levels and bio- organics on yield and nutrient removal of basmati rice $\mathrm{cv}$. HUBR-10- 9. The Bioscan.11(1), 555558

Olsen, S. R., Cole, C. V., Watanable, F. S. and Dean, L. A. (1954) Estimation of available phosphorus in soils by extraction with sodium bicarbonate. USDA Circular 939.

Rondon, M. A., Lehmann, J., Ramírez, J., \& Hurtado, M. (2007). Biological nitrogen fixation by common beans (Phaseolus vulgaris L.) increases with bio-char additions. Biology and fertility of soils, 43(6), 699-708.

Shanta, N. K, (2012). Biochar and PGPR as Methods for Low-input Management of Bioenergy Grasses. M. Sc. Thesis, submitted to McGill University, Macdonald Campus, Quebec,

Canada pp.

Sparks, D. L. (1996) Methods of soil analysis. Part 3-Chemical Methods. Soil Science Society of America Inc., American Society of Agronomy Inc., Madison Wisconsin, USA.

Subbiah, B. V., and Asija, G. L. (1956) Alkaline method for determination of mineralizable nitrogen. Current Science. 25, 259-260.

Van Zwieten, L., Kimber, S., Morris, S., Chan, K. Y., Downie, A., Rust, J., ... \& Cowie, A. (2010). Effects of biochar from slow pyrolysis of paper mill waste on agronomic performance and soilfertility. Plantand soil, 327(12), 235-246.

Vassilev, N., Vassileva, M., \&Nikolaeva, I. (2006). Simultaneous P-solubilizing and biocontrol activity of microorganisms: potentials and future trends. Applied microbiology and biotechnology, 71(2), 137-144.

Walkley, A., and Black, I. A. (1934) An examination of the Degtjareff method for determining soil organic matter, and a proposed modification of the chromic acid titration method. Soil Science, 37(1), 29-38.

\section{How to cite this article:}

Ayush Bahuguna, Sachin Sharma, Janardan Yadav and Neelam Yadav. 2020. Effect of Biochar, Carpet Waste, FYM and PGPR on Growth and Yield of Rice under Organic Farming System. Int.J.Curr.Microbiol.App.Sci. 9(03): 1450-1456. doi: https://doi.org/10.20546/ijcmas.2020.903.169 